\title{
INTEGRASI SISTEM PENDIDIKAN \\ PESANTREN DAN SEKOLAH
}

\author{
Oleh: Imam Taulabi ${ }^{*}$
}

\begin{abstract}
Abstrak
Konsep integrasi sebagai wujud modernisasi sistem pendidikan, dalam artian pesantren dan sekolah menjadi satu sistem yang satu. Lembaga pendidikan sebagai suatu sistem, mencakup beberapa komponen, dan setiap komponen terdiri dari beberapa faktor. Satu sama lainnya saling terkait sehingga membentuk suatu sistem. Komponen tersebut, terdiri dari masukan (input), proses (process), keluaran langsung (output) dan keluaran tidak langsung (outcome). Integrasi antara pesantren dan sekolah sebagai salah satu upaya untuk membentuk keseimbangan antara kecerdasan intelektual dan kecerdasan spiritual. Kecerdasan intelektual tanpa disertai dengan kecerdasan spiritual menjadi kehilangan karakter dan jati dirinya.
\end{abstract}

Key Words: Integrasi, Pesantren, dan Sekolah

\section{Konteks Penelitian}

Ada fenomena menarik yang berkembang di era modern dalam dunia pendidikan, setidaknya dikenal tiga lembaga pendidikan yang cukup eksis di Indonesia yaitu sekolah, madrasah dan pondok pesantren. ${ }^{1}$ Dalam perkembangannya ketiga lembaga ini membentuk kolaborasi yang saling bersinergi. Setidaknya lembaga yang berkembang sekarang merupakan perpaduan dari lembaga pesantren dan madrasah yang dipandang cukup wajar dan lumrah di tengah masyarakat. Namun pada perkembangan berikutnya lembaga pesantren berintegrasi dengan lembaga sekolah, yang notabennya berbesik umum. Dengan kata lain, lingkup dan sifat pendidikan yang dilakukan dalam dunia pendidikan bisa meliputi pendidikan

* Institut Agama Islam Tribakti (IAIT) Kediri

${ }^{1}$ Ali Anwar, Pembaharuan Pendidikan di Pesantren Lirboyo, (Kediri: IAIT Press, 2008), h. 1. 
formal dan non-formal. ${ }^{2}$ Pendidikan formal dapat diwakili melalui sekolah, sedangkan non formal berupa pesantren.

Dua lembaga pendidikan (sekolah dan pesantren) mempunyai banyak perbedaan. Sekolah (lembaga pendidikan formal) identik dengan kemodernan, sedangkan pesantren identik dengan ketradisionalan. Sekolah lebih menekankan pendekatan yang bersifat liberal, pesantren lebih pada sikap normatif yang bersandar dan berpusat pada figur sang kyai. ${ }^{3}$ Namun, persepsi dualisme-dikotomik semacam ini mungkin kurang begitu tepat, karena dalam kenyataannya, banyak pula pesantren yang telah melakukan perubahan baik secara struktural maupun kultural.

Hal ini, menunjukan bahwa sistem pendidikan itu pada dasarnya selalu mengalami perubahan sesuai hukum alam, yaitu mengalami proses semakin menua dan menjadi aus, sehingga tidak lagi sanggup menangani kebutuhan baru masyarakat sekitar yang sifatnya penting. ${ }^{4}$ Artinya bahwa sebuah sistem pendidikan akan mengalami satu proses perubahan di mana dua sistem pendidikan yang dibedakan dengan pendidikan formal dan non formal keduannya dapat saja dilakukan penyatuan untuk menemukan satu konsep baru pendidikan. Satu hal yang tidak dapat dipungkiri bahwa pendidikan non formal telah banyak melakukan perubahan pada masyarakat di Indonesia.

Keunikan pesantren (non formal) tampak pada sistem pembelajaran yang diterapkan, berbeda dengan lembaga pendidikan pada umumnya, terutama berkenaan dengan pola pembelajaran tradisional dengan ciri khasnya yakni: sorogan, bandongan dan wetonan. ${ }^{5}$ Namun kemudian seiring dengan perkembangan zaman pesantren sebagai lembaga pendidikan

2 Ahmad Arifi, Politik Pendidikan Islam: Menelusuri Ideologi dan Aktualisasi Pendidikan Islam di Tengah Arus Globalisasi (Yogyakarta: Teras, 2009), h. 5.

3 Mudjia Rahardjo, Ed. Quo Vadis Pendidikan Islam: Membaca Realitas Pendidikan Islam, Sosial dan Keagamaan. Malang : UIN-Malang Press, 2006, xxi.

4 Kartini Kartono, Tinjauan Politik Mengenai Sistem Pendidikan Nasional Beberapa Kritik dan Sugesti (Jakarta:Pradnya Paramita,1997), h. 47.

${ }^{5}$ Arifi, Politik Pendidikan Islam, h. 39. 
menyelenggarakan bentuk-bentuk pendidikan yang sangat bervariasi, di antaranya adalah dengan melaksanakan sistem integrasi dengan tetap mempertahankan ciri khas dan keaslian yang sudah ada sekaligus mengadopsi sistem persekolahan yang klasikal-formal. ${ }^{6}$ Yang dikehendaki dalam hal ini adalah sistem pendidikan terpadu yaitu lembaga pendidikan pondok pesantren yang memiliki kondisi obyektif riil, yang secara kultural dan kelembagaannya terintegrasi dengan sistem sekolah formal maupun non formal yang berada di lingkungan pesantren (madrasah diniyah). ${ }^{7}$

Dilihat dari kurikulumnya, ciri kurikulum pesantren memadukan penguasaan sumber ajaran Ila $>$ hi (bersumber dari Allah SWT) menjadi peragaan individual untuk disemaikan ke dalam hidup bermasyarakat. Selain mengenalkan ranah kognitif (pengetahuan), afektif (sikap), dan psikomotorik (perilaku) dalam pengajarannya, sejak lama pesantren mendasarkan diri pada tiga ranah utama; yaitu faqohah (kecukupan atau kedalaman pemahaman agama), $t\} a b i$ 'ah (perangai, watak, atau karakter), dan kafa'ah (kecakapan operasional). ${ }^{8}$ Jika pendidikan merupakan upaya perubahan, maka yang dirubah adalah tiga ranah tersebut, dan tentu saja perubahan ke arah yang lebih baik. Secara substansial, pesantren merupakan institusi pendidikan keagamaan yang tidak mungkin lepas dari masyarakat, khususnya masyarakat pedesaan. Oleh karena lembaga ini tumbuh dan berkembang dari masyarakat dan untuk masyarakat dengan memposisikan dirinya sebagai bagian dari masyarakat dalam pengertian transformatif. Dalam konteks ini, pendidikan pesantren pada dasarnya merupakan pendidikan yang sarat dengan nuansa transformasi sosial.

Menurut Pupuh Fatkhurrahman bahwa tipe pendidikan ideal model pendidikan pondok pesantren yang dapat

${ }^{6}$ M. Sulthon Masyhud dan Moh. Khusnurdilo, Manajemen Pondok Pesantren (Jakarta: Diva Pustaka, 2003), h. iv.

7 Pupuh Fathurrahman, Pengembangan Sistem Pondok Pesantren Analisis terhadap Keunggulan Sistem Pendidikan Terpadu dalam buku Cakrawala Pemikiran Pendidikan Islam (Bandung: Mimbar Pustaka, 2004), h. 195.

${ }^{8}$ M. Dian Nafi' (ed). Praksis Pembelajaran Pesantren, (Yogyakarta: El-Kis, 2007), h. 33. 
dikembangkan saat ini adalah tipe integrasi antara sistem pendidikan formal dan pendidikan non formal (diniyah). Penerapan sistem ini tidak mempertentangkan jenis, bentuk, jenjang dan tujuannya, tetapi pemaduannya dengan harmonis seimbang sehingga merupakan sistem yang berkelanjutan dan saling mengisi serta merupakan sintesa konvergensi atau bersinegritas. ${ }^{9}$ Dalam pelaksanaannya melalui sistem integrasi ini santri bisa mendapatkan pendidikan dalam situasi lingkungan sosial keagamaan yang kuat dengan ilmu pengetahuan agama yang juga dilengkapi dengan ilmu pengetahuan umum sebagai bekal hidup bermasyarakat. ${ }^{10}$

Dari uraian di atas, kajian ini akan mengurakan secara konsep tual integrasi sistem pendidikan Islam. Dimaksud di sini adalah suatu cara atau sarana yang berupa perangkat organisasi untuk mencapai tujuan baik melalui jalur pendidikan formal maupun pendidikan diniyah. Dengan istilah lain sering disebut juga dengan sekolah berbasis pesantren (SBP).

\section{Pengertian, Sejarah dan Perkembangan Pondok Pesantren}

Menurut Rid\}wa $>n$ Nas $\} \mathrm{i}>\mathrm{r}$, pondok pesantren adalah lembaga keagamaan yang memberikan pendidikan dan pengajaran serta mengembangkan dan menyebarkan agama Islam. ${ }^{11}$ Zuhairini berpendapat pondok pesantren adalah tempat murid-murid (disebut santri) mengaji agama Islam dan sekaligus diasramakan di tempat itu. ${ }^{12}$ Sementara itu, Nurcholish Madjid, pesantren adalah bentuk pendidikan Islam di Indonesia yang telah berakar sejak berabad-abad silam. Ia menilai, pesantren mengandung makna ke-Islam-an sekaligus keaslian (indigenous) Indonesia. Kata "pesantren" mengandung pengertian sebagai tempat para santri atau murid pesantren. Sedangkan kata "santri" diduga berasal dari istilah sansekerta "sastri" yang berarti

\footnotetext{
${ }^{9}$ Ibid., h. 216.

10 Djamaluddi $>$ n dan 'Abdulla $>$ h A $>$ ly, Kapita Selekta Pendidikan Islam (Bandung: Pustaka Setia, 1999), h. 101.

11 Rid $\}$ wa $>$ n Nas $\}$ i $>$ r, Mencari Tipologi Format Pendidikan Ideal Pondok Pesantren di Tengah Arus Perubahan (Yogyakarta: Pustaka Pelajar, 2005), h.80.

${ }^{12}$ Zuhairini, Sejarah Pendidikan Islam (Jakarta: Bumi Aksara, 2004), h. 212 .
} 
"melek huruf", atau dari bahasa Jawa "cantrik" yang berarti seseorang yang mengikuti gurunya kemana pun dia pergi. ${ }^{13}$ Jadi yang dimaksud dengan pondok pesantren menurut penulis adalah suatu lembaga pendidikan agama Islam tertua di Indonesia yang mempunyai karakteristik yang unik dan menarik dalam segi manajemen, kurikulum, metode, sarana prasarana maupun adat istiadat yang dipeganginya, sehingga dianggap produk budaya yang indigenous.

Pondok pesantren, dilihat dari segi latar belakang historisnya tumbuh dan berkembang dengan sendirinya dalam masyarakat dimana terdapat implikasi-implikasi politis dan kultural yang menggambarkan sikap ulama-ulama Islam sepanjang sejarah. ${ }^{14}$ Ia lahir dan berkembang semenjak masamasa permulaan kedatangan Islam di negeri ini. Ia mulai berdiri karena adanya seorang figur guru yang layak menjadi Kyai, baik karena ilmu agamanya, maupun akhlak dan kharisma yang dimilikinya. ${ }^{15}$ Pondok pesantren menurut akar berdirinya ditemukan dua versi. Pertama, pendapat yang mengatakan bahwa pondok pesantren berakar pada tradisi Islam sendiri yaitu tradisi tarekat. Pendapat ini berdasarkan fakta bahwa penyiaran Islam di Indonesia pada awalnya lebih banyak dikenal dalam bentuk kegiatan tarekat. Kedua, pondok pesantren merupakan pengambil alihan dari sistem pondok pesantren yang diadakan orang-orang Hindu di Nusantara. Hal ini didasarkan fakta bahwa jauh sebelum datangnya Islam ke Indonesia lembaga pondok pesantren telah ada di negeri ini. ${ }^{16}$

Pondok pesantren di Indonesia baru diketahui keberadaannya dan perkembangannya setelah abad ke-16. Karya-karya jawa klasik seperti serat cabolek dan serat centini

\footnotetext{
13 Nabil Hzusein, “ Sejarah Pondok Pesantren”, http://nabilhusein.com/, diakses tanggal 31 Maret 2013.

${ }^{14}$ A $>$ ly, Kapita Selekta, h. 99.

15 Sejarah pesantren tepi seperti ini hanya di Jawa dan Madura. Apabila melihat di Kalimatan dan Sulawesi pesantren dibangun tidak didasarkan pada figur Kyai, tetapi biasanya dibuat oleh seorang penguasa baik itu, Tetua Adar, Raja, Pemerintah (sekarang) dengan mengagkat seorang pemimpin pesantren.

${ }^{16}$ Haidar Putra Dauly, Historisitas dan Eksisitensi Pesantren Sekolah dan Madrasah, (Yoyakarta: PT. Tiara Wacana Yogya, 2001), h. 8
} 
mengungkapkan bahwa sejak permulaan abad ke-16 ini di Indonesia telah dijumpai lembaga-lembaga yang mengajarkan berbagai kitab Islam klasik bidang fiqih, akidah, tasawuf dan yang menjadi pusat-pusat penyiaran Islam yaitu pondok pesantren. Selanjutnya, terbentuknya pondok pesantren menjadi lembaga pendidikan agama Islam tertua di Indonesia muncul bersamaan dengan proses Islamisasi di bumi Nusantara pada abad ke-18 dan ke-19 masehi dan terus berkembang sampai saat ini. ${ }^{17}$ Seiring dengan perkembangan zaman, pondok pesantren dituntut untuk mengadakan pembaharuan atau inovasi diri baik dalam lembaga pendidikannya, manajemen, kurikulum, materi pelajaran, model pendidikan serta sarana dan prasarananya.

Sementara itu, yang menjadi ciri khas pesantren sekaligus menunjukkan unsur-unsur pokoknya yang membedakannya dengan lembaga pendidikan lainnya yaitu pondok, masjid, santri, pengajaran kitab-kitab klasik, dan kyai. ${ }^{18}$ Sedangkan Soedjoko Piasodjo menggambarkan bahwa elemen dasar dan tradisi pesantren tergantung dan pola pesantrennya, dari yang paling sederhana sampai yang paling maju. Pola I ialah pesantren yang terdiri dari hanya masjid dan rumah kyai, Pola II ialah pesantren yang terdiri dan masjid, rumah kyai, dan pondok. Pola III ialah pesantren yang terdiri dan masjid, rumah kyai, pondok dan madrasah. Pola IV terdiri dan masjid, rumah kyai, pondok, madrasah, dan tempat keterampilan. Dan Pola V ialah pesantren yang terdiri dari masjid, rumah kyai, pondok, madrasah, tempat keterampilan, universitas, gedung pertemuan, tempat olah raga dan sekolah umum. ${ }^{19}$

\section{Materi dan Metode Pembelajaran di Pesantren}

Pada dasarnya pesantren hanya mengajarkan ilmu dengan sumber kajian atau mata pelajarannya kitab-kitab yang ditulis atau berbahasa Arab. Ilmu tersebut lebih bersifat normatif dengan mengunakan penalaran deduktif, dengan penyelenggaraan pola pendidikan yang beragam, namun tetap mempunyai fungsi yang sama, yakni mendidik dan mengajarkan

\footnotetext{
${ }^{17}$ Enung K Rukiati dan Fenti Hikmawati, Sejarah Pendidikan Islam di Indonesia (Bandung: Pustaka Setia,2006), h.103.

${ }^{18}$ Hikmawati, Sejarah, h. 104.

${ }^{19}$ Nabil Husein, " Sejarah Pondok Pesantren”
} 
ilmu-ilmu agama Islam sebagai upaya mewujudkan manusia yang tafaqquh $f i$ al-di>n (paham terhadap agama), karena hampir seluruh pesantren di Indonesia mengajarkan mata pelajaran yang sama. Di antara sumber-sumber kajian tersebut mencakup al Qur'an beserta tajwi $>$ d dan tafsirnya, aqa $>$ 'id dan ilmu kala $>$ m, fiqh dan us $\} \mathrm{u}>1$ fiqh, al-hadis $\backslash$ dan must $\}$ alah $\}$ ah al-hadis $\backslash$, bahasa Arab dengan seperangkat ilmu alatnya, seperti nah\}wu, s\} araf, baya $>$ n, ma'a $>$ ni, badi' dan 'aru $>z$ \}, tarikh, mantiq dan tasawuf. Sumber-sumber kajian ini biasa disebut sebagai "kita $>$ b-kita $>b$ kuning". ${ }^{20}$ Dua materi terakhir ini biasanya diberikan pada pengajian tingkat lanjutan. Sementara itu ada pula pesantren yang memberikan ilmu falak secara mendalam, karena Kyai sebagai tokoh pokok dalam pesantren maka masing-masing pesantren mempunyai keistimewaan sendiri-sendiri dalam fak tertentu sesuai dengan keahlian masing-masing. Bagaimana pun bentuk pesantren, pada prinsipnya kurikulum Pesantren itu meliputi seluruh kegiatan yang dilakukan selama sehari semalam.

Menurut 'Abdulla $>\mathrm{h} A>\mathrm{ly}$, dalam rangka mencapai tujuan diperlukan suatu metode yang sangat operasional pula, yaitu metode penyajian dan pengajaran materi pelajaran yang ditetapkan di pondok pesantren. Metode tersebut ada yang bersifat tradisional menurut kebiasaan-kebiasaan yang lama dipergunakan dalam institusi tersebut, seperti pengajian dengan hafalan, wetonan dan sorogan. Metode hafalan berlangsung dimana santri menghafal teks atau kalimat tertentu dari kitab yang dipelajarinya. Materi hafalan biasanya dalam bentuk syiir atau nadhom. Sebagai pelengkap metode hafalan sangat efektif untuk memelihara daya ingat (memorizing) santri terhadap materi yang dipelajarinya, karena dapat dilakukan baik di dalam maupun di luar kelas. Adapun metode wetonan merupakan metode kuliah dimana para santri mengikuti pelajaran dengan duduk di sekeliling kyai yang menerangkan pelajaran. Sedangkan metode sorogan sedikit berbeda dari metode

${ }^{20}$ H.M. Sulthon Masyhud dan Moh. Khusnurdilo, Manajemen Pondok Pesantren (Jakarta: Diva Pustaka, 2003), h. 89. 
wetonan dimana santri mengahadap guru satu persatu dengan membawa kitab yang dipelajari sendiri. ${ }^{21}$

Selain itu ada juga metode non tradisional dengan pengertian metode yang baru diintrodusir ke dalam institusi tersebut berdasarkan pendekatan ilmiah. Biasanya ada kecenderungan di kalangan pondok pesantren untuk mempertahankan metode tradisional yang telah berlangsung secara turun temurun, sedangkan metode-metode baru sering kali kurang mendapat simpati. Keadaan demikian banyak terpengaruh oleh sikap apakah pimpinannya introvert dan extrovert. Oleh karena itu, dalam usaha memajukan dan mendayagunakan serta menghasilgunakan metode-metode baru perlu dilakukan pendekatan-pendekatan yang bijaksana kepada para pengasuh pondok pesantren. ${ }^{22}$

Untuk memudahkan semua metode tersebut di atas dalam pencapaian tujuan pembelajaran secara maksimal, maka perlu adanya suatu pendekatan. Di antara pendekatan pembelajaran di pesantren adalah pendekatan psikologis (tekanan utamanya adalah motivasi kyai kepada santrinya dengan persuasif yaitu dorongan yang menggerakkan daya kognitif, afektif dan psikomotorik), pendekatan sosio kultural (usaha pengembangan sikap-sikap pribadi dan sosial sesuai dengan fenomena masyarakat), pendekatan religik (penjelasan bahwa semua ilmu yang diajarkan berkosekuensi keimanan mentauhidkan Allah), pendekatan historis (pengarahan pembelajaran dalam menggunakan pengalaman, kejadian, peristiwa atau sejarah umat dan sebagainya), pendekatan filosofis (pendekatan dengan penalaran atau pemikiran dalam menelaah materi pelajaran) dan pendekatan komparatif (pendekatan yang dilakukan dengan membandingkan suatu gejala sosial keagamaan dengan hukum agama yang ditetapkan selaras dengan situasi dan zamannya). ${ }^{23}$

\section{Pengertian, Objek Pendidikan Formal (sekolah)}

Pendidikan formal adalah kegiatan yang sistematis, berstruktur, bertingkat, berjenjang, dimulai dari sekolah dasar sampai dengan perguruan tinggi dan yang setaraf dengannya,

\footnotetext{
${ }^{21}$ Khusnurdilo, Manajemen, h. 89.

${ }^{22}$ Aly, Kapita Selekta, h. 116.

${ }^{23}$ Ibid, h. 119.
} 
termasuk ke dalamnya kegiatan studi yang berorientasi akademis dan umum, program spesialisasi dan latihan professional, yang dilaksanakan dalam waktu yang terus menerus. $^{24}$ Sistem pendidikan formal yang dimaksud disini adalah suatu kesatuan yang merupakan keseluruhan yang terorganisir berupa usaha untuk mewujudkan pendidikan bangsa dan tujuan nasional pendidikan berdasarkan perkembangan dan kebutuhan zaman sesuai dengan jiwa (bakat dan minat) serta bentuk kurikulum yang dicanangkan oleh pemerintah melalui jalur pendidikan formal.

Obyek dari pendidikan formal adalah peserta didik sebagai generasi penerus bangsa yang berkualitas dalam segi intelek dan segi moral, karena pendidikan nasional pada hakekatnya adalah satu kesatuan yang bulat dari input, proses maupun output-nya, sehingga hal tersebut harus disesuaikan dengan tujuan Pendidikan Nasional Indonesia yang tercantum dalam UU Sisdiknas No. 20 Tahun 2003 pasal 3:

Pendidikan Nasional berfungsi mengembangkan kemampuan dan membentuk watak serta peradaban bangsa yang bermartabat dalam rangka mencerdaskan bangsa, bertujuan untuk mengembangkan peserta didik agar menjadi manusia yang beriman dan bertaqwa kepada Tuhan Yang Maha Esa, berakhlaq mulia, sehat, berilmu, cakap, kreatif, mandiri dan menjadi warga Negara yang demokratis dan bertanggung jawab. ${ }^{25}$

Secara umum Jusuf Amir Faesal mengungkap bahwa sistem pendidikan nasional yakni suatu usaha keseluruhan yang terpadu dari semua satuan dan kegiatan pendidikan yang berkaitan satu dengan lainnya untuk mengusahakan tercapainya tujuan pendidikan nasional. Atau ringkasnya, sistem pendidikan nasional adalah satu pranata dari sejumlah pranata yang berada

${ }^{24}$ Sudjana S, Pendidikan Nonformal, h. 22.

${ }^{25}$ Undang-Undang Republik Indonesia Nomor 20 Tahun 2003 tentang "Sistem Pendidikan Nasional" ( Jakarta: Asa Mandiri, 2008), h. 67. 
dalam sistem pendidikan nasional. ${ }^{26}$ Dari berbagai pengertian di atas, kesimpulan sederhana mengenai sistem pendidikan nasional secara filosofis adalah satu kesatuan yang utuh dan menyeluruh yang saling bertautan dan berhubungan dalam sistem pendidikan nasional untuk mencapai tujuan pendidikan nasional secara umum. Sedangkan sistem pendidikan terutama pada aspek kurikulum, siswa, guru, proses pembelajaran, dan aspek partisipasi masyarakat.

\section{Model Pembelajaran}

Adapun yang termasuk model pembelajaran dalam sistem pendidikan formal antara lain adalah:

1. Metode Tanya Jawab (Dialogis) yaitu metode dengan tujuan untuk mengetahui ingatan anak menguasai bahan pelajaran yang telah dipelajari.

2. Metode Demonstrasi dan Eksperimen; metode demonstrasi adalah metode mengajar dengan memperlihatkan kepada seluruh kelas tentang suatu proses atau cara melakukan sesuatu. Sedangkan metode eksperimen adalah suatu cara mengajar dengan melakukan praktek atau percobaan serta pengamatan tentang proses dan hasil percobaan suatu ilmu pengetahuan.

3. Metode Pemecahan Masalah (Problem Solving) adalah siswa dilatih memecahkan masalah secara mandiri atau bersamasama.

4. Metode Pemberian Tugas Belajar (Resitasi) adalah pemberian tugas khusus kepada murid untuk mengerjakan sesuatu di luar jam pelajaran.

5. Metode Latihan Siap (Drill) adalah cara guru melatih ketangkasan atau ketrampilan para murid terhadap pelajaran yang telah disampaikan.

6. Metode Ceramah adalah cara mengajar secara lisan untuk memberitahu, menjelaskan, menerangkan atau memberi petunjuk dalam sebuah ruangan, waktu dan bahan yang sama.

\footnotetext{
${ }^{26}$ http://zulkarnainyani.wordpress.com/2008/04/22/sistem-pendidikannasional-sebuah-pengertian-filosofis-2/
}

Volume 24 Nomor 2 September 2013 
7. Metode Sosiodrama dan Bermain Peranan adalah usaha guru dalam menirukan tingkah laku dari situasi sosial serta keikutsertaannya dalam memainkan suatu peran.

8. Metode Diskusi adalah metode mendiskusikan suatu mata pelajaran tertentu, sehingga menimbulkan pengertian serta perubahan tingkah laku murid.

9. Metode Tes adalah metode mengajar dengan jalan memberikan tes kepada siswa untuk mengetahui kemampuan dalam kegiatan belajar mengajar. ${ }^{27}$

Selain metode-metode tersebut di atas juga ada suatu sistem atau metode pembelajaran berdasarkan kurikulum berbasis kompetensi (KBK) yaitu Sistem Pembelajaran Kontekstual, adalah konsep belajar yang mengaitkan antara materi yang diajarkan dengan situasi dunia nyata siswa dan mendorong siswa menghubungkan pengetahuan yang dimilikinya dengan persoalan hidup sehari-hari. KBK pada dasarnya adalah proses belajar mengajar yang berlangsung dalam rangka pengkonstruksian dan penyusunan pengetahuan oleh peserta didik dengan cara memberi makna dan merespons ilmu pengetahuan sebelumnya. ${ }^{28}$

Dewasa ini yang terkenal dan digunakan di lembagalembaga formal adalah model pembelajaran dengan menerapkan kurikulum yang disusun dan dilaksanakan di masing-masing satuan pendidikan yang sering disebut dengan KTSP. KTSP terdiri dari tujuan pendidikan tingkat satuan pendidikan, struktur dan muatan kurikulum tingkat satuan pendidikan, kalender pendidikan dan silabus. ${ }^{29}$ KTSP dikembangkan sesuai dengan relevansinya oleh setiap satuan pendidikan di bawah koordinasi dan supervisi Kemendigbud atau Kemenag berdasarkan prinsipprinsip sebagai berikut: (1) Berpusat pada potensi, perkembangan, kebutuhan dan kepentingan peserta didik dan lingkungannya, (2) beragam dan terpadu, (3) tanggap terhadap perkembangan ilmu pengetahuan, teknologi dan seni, (4) relevan

${ }^{27}$ Roestiyah N.K., Strategi Belajar Mengajar (Jakarta: Rineka Cipta, 2001), h. 83-136.

${ }^{28}$ Hamzah. B. Uno, Perencanaan Pembelajaran (Jakarta: Bumi Aksara, 2009), h. 121.

${ }^{29}$ Ibid, h. 79. 
dengan kebutuhan hidup, (5) menyeluruh dan berkesinambungan, (6) belajar sepanjang hayat dan (7) seimbang antara kepentingan nasional dan kepentingan daerah.

Selanjutnya yang merupakan proses akhir dari sebuah pembelajaran yang telah dilaksanakan tentunya harus diadakan evaluasi guna mengetahui tingkat keberhasilan dalam penyampaian suatu materi pelajaran dengan menggunakan sistem atau metode tertentu. Evaluasi hasil belajar peserta didik dilakukan oleh pendidik untuk memantau proses, kemajuan dan perbaikan hasil belajar peserta didik secara berkesinambungan baik melalui evaluasi akhir semester, akhir tahun maupun akhir suatu jenjang pendidikan dengan mengadakan ujian akhir sekolah. $^{30}$ Evaluasi dalam arti luas adalah suatu proses merencanakan, memperoleh, dan menyediakan informasi yang sangat diperlukan untuk membuat alternatif-alternatif keputusan sampai sejauh mana tujuan-tujuan pendidikan dicapai oleh siswa. $^{31}$

\section{Integrasi Kurikulum, Pembelajaran dan Evaluasi Pendidikan}

Menururt Didik keseimbangan antara kecerdasan intelektual dan kecerdasan spiritual anak bangsa multak dibutuhkan demi keberlangsungan masa depan bangsa ini. Kecerdasan intelektual tanpa disertai dengan kecerdasan spiritual akan membuat bangsa Indonesia menjadi bangsa yang kehilangan karakter dan jati dirinya. ${ }^{32}$ Di samping itu dapat juga disebut sebagai pembaharuan sistem pendidikan yang terjadi di pesantren. ${ }^{33}$ Dengan demikian integrasi sistem pendidikan antara pesantren dan sekolah menjadi suatu kebutuhan yang dapat

16

30 Hari Suderajat, Implementasi Kurikulum Berbasis Kompetensi, h.

${ }^{31}$ Ngalim Purwanto, Prinsip-prinsip dan Teknik Evaluasi Pengajaran (Jakarta : PT Remaja Rosdakarya, 2000), h. 3.

${ }^{32}$ Didik Suhardi, "Peran SMP Berbasis Pesantren Sebagai Upaya Penanaman Pendidikan Karakter Kepada Generasi Bangsa", Jurnal Pendidikan Karakter, Tahun II, Nomor 3, Oktober 2012.

${ }^{33}$ Ali Anwar, "Pembaharuan Pendidikan di Pesantren: Studi Kasus Pesantren Lirboyo Kediri”. Disertasi Tidak Ditebitkan, (Jakarta: Universitas Islam Negeri Sayarif Hidayatullah, 2008), h. 6. 
diintegasikan dalam konsep mikro pada tiga aspek: kurikulum, pembelajaran dan evaluasi.

Kurikulum dalam disiplin ilmu pendidikan, meliputi tiga jenis materi yaitu: ilmu pengetahuan (kognitif), keterampilan (psikomotorik) dan materi yang memiliki nilai-nilai afektif. Ketiga materi inilah yang membentuk materi pendidikan yang berbentuk disiplin ilmu pengetahuan. Dalam prakteknya, seharusnya antara ilmu pengetahuan yang berdasarkan wahyu dengan pemikiran akal tidak bertentangan. Keduanya dapat diintegrasikan dijadikan isi materi kurikulum. Pengintegrasian ini dilakukan atas dasar beberapa alasan: pertama, diharapkan dengan integrasi kurikulum tersebut akan melahirkan out put yang mempunyai pengamatan yang terintegritas dengan realitas, artinya inti pengetahuan adalah kebenaran atas realitas yang memberi kebahagiaan di dunia dan akhirat. Kedua, integrasi kurikulum dapat menghasilkan manusia yang memiliki kepribadian yang terpadu pula (integrated personality). Ketiga, diharapkan melalui kandungan kurikulum yang terintegrasi antara pengetahuan umum dengan pengetahuan agama akan menimbulkan perpaduan di kalangan masyarakat, berhubungan secara secara harmonis. ${ }^{34}$

Selanjutnya, integrasi kurikulum harus seimbang dan harmonis antara pendidikan umum dan pendidikan agama yang berkualitas dengan kebutuhan masyarakat madani dan global, sehingga program-program kurikulum juga harus diharapkan sesuai kebutuhan masa sekarang dan masa depan, tidak lagi bersifat terpisah-pisah (parsial), melainkan memadukan berbagai ilmu pengetahuan baik umum maupun agama, yang bersumber pada pemikiran akal maupun wahyu. Dengan demikian, diharapkan mampu melahirkan manusia muslim yang berkualitas dan mampu hidup dalam persaingan yang ketat yang dapat mengikuti tuntutan dan perubahan zaman dengan tidak merusak akidah dan akhlaq mulia, sehingga selamat dan sejahtera di dunia maupun di akhirat. ${ }^{35}$

${ }^{34}$ Hasan Langgulung, Manusia dan Pendidikan (Jakarta: Pustaka AlHusna, 1986), h. 195.

35 Pupuh FathurraMan, Pengembangan Sistem Pondok Pesantren Analisis terhadap Keunggulan Sistem Pendidikan Terpadu dalam buku 
Selanjutnya, mengenai integrasi Sistem pembelajaran, dalam hal ini harus berupaya menghindari kontaminasi yang ditimbulkan sistem pembelajaran sekuler, yakni hanya mementingkan kecerdasan dan hanya untuk secarik penghargaan untuk mendapatkan ijazah dan gelar di dunia. Dalam memadukan sistem pembelajaran sebaiknya juga memperhatikan dan memelihara keaslian belajar mengajar yaitu didasari keikhlasan karena Allah SWT. Pelaksanaan sistem pembelajaran harus memadukan keterkaitan antara satu materi dengan materi yang lainnya secara harmonis dan dikaitkan dengan potensi dan kebutuhan peserta didik untuk masa sekarang dan masa akan datang. ${ }^{36}$

Demikian juga kaitannya dengan evaluasi pendidikan, secara riil, sistem evaluasi pendidikan nasional di Indonesia saat ini dikeluhkan oleh masyarakat, terutama para ahli pendidikan, yaitu terdapatnya evaluasi yang tidak terpadu. Sistem pendidikan nasional melakukan kesalahan besar dalam melaksanakan evaluasi keberhasilan pendidikannya, hanya diukur dan dikerdilkan ke dalam keberhasilan akademis yang tidak diwujudkan ke dalam keunggulan watak pribadi dan ketaqwaaan. Oleh karenanya, adanya integrasi kurikulum yang diterapkan di Pondok Pesantren harus berupaya mengembangkan evaluasi yang terpadu dengan mengukur keberhasilan tidak hanya dari segi prestasi akademik, tingkat kecerdasan melainkan juga berdasarkan ketaqwaan dan amal sholeh. $^{37}$

Cakrawala Pemikiran Pendidikan Islam (Bandung: Mimbar Pustaka, 2004), h. 225.

$$
\begin{aligned}
& { }^{36} \text { Ibid, h. } 230 . \\
& { }^{37} \text { Ibid }
\end{aligned}
$$




\section{Daftar Pustaka}

Arifi, Ah\}mad, Politik Pendidikan Islam: Menelusuri Ideologi dan Aktualisasi Pendidikan Islam di Tengah Arus Globalisasi, Yogyakarta: Teras, 2009.

Djamaluddi $>$ n dan 'Abdulla $>$ h A $>1 y$, Kapita Selekta Pendidikan Islam, Bandung: Pustaka Setia, 1999.

Fath\}urrahma $>\mathrm{n}$, Pupuh, Pengembangan Sistem Pondok Pesantren Analisis terhadap Keunggulan Sistem Pendidikan Terpadu dalam buku Cakrawala Pemikiran Pendidikan Islam, Bandung: Mimbar Pustaka, 2004.

http://zulkarnainyani.wordpress.com/2008/04/22/sistempendidikan-nasional-sebuah-pengertian-filosofis-2/Husein, Nabil, "Sejarah Pondok Pesantren", http://nabilhusein.com/, diakses tanggal 31 Maret 2013.

Isnaini, Muh $\}$ ammad, "Studi Evaluasi Penyelenggaran Pendidikan Diniyah di Indonesia", http://wasiatjakarta.blogspot.com/2008/10/, diakses 10 April 2013.

Kartono, Kartini, Tinjauan Politik Mengenai Sistem Pendidikan Nasional Beberapa Kritik dan Sugesti, Jakarta:Pradnya Paramita,1997.

Langgulung, Hasan, Manusia dan Pendidikan, Jakarta: Pustaka Al-Husna, 1986.

Masyhud, M. Sulthon, dan Moh. Khusnurdilo, Manajemen Pondok Pesantren, Jakarta: Diva Pustaka, 2003.

Nafi', M. Dian, (ed). Praksis Pembelajaran Pesantren, Yogyakarta: El-Kis, 2007. 
Nasi>r, Rid\}wa>n, Mencari Tipologi Format Pendidikan Ideal Pondok Pesantren di Tengah Arus Perubahan, Yogyakarta: Pustaka Pelajar, 2005.

"Pesantren Dalam Sisdiknas", http://researchengines.com/achumaedy.html, diakses tanggal 7 Februari 2012.

Peraturan Pemerintah RI No 55 Tahun 2007 Tentang Pendidikan Agama dan Pendidikan Keagamaan.

Purwanto, Ngalim, Prinsip-prinsip dan Teknik Evaluasi Pengajaran, Jakarta: PT Remaja Rosdakarya, 2000.

Rahardjo, Mudjia, Ed. Quo Vadis Pendidikan Islam: Membaca Realitas Pendidikan Islam, Sosial dan Keagamaan. Malang: UIN-Malang Press, 2006.

Roestiyah, N.K., Strategi Belajar Mengajar, Jakarta: Rineka Cipta, 2001.

Rukiati, Enung K., dan Fenti Hikmawati, Sejarah Pendidikan Islam di Indonesia, Bandung: Pustaka Setia, 2006.

Suhardi, Didik, "Peran SMP Berbasis Pesantren Sebagai Upaya Penanaman Pendidikan Karakter Kepada Generasi Bangsa", Jurnal Pendidikan Karakter, Tahun II, Nomor 3, Oktober 2012.

Syuhud, Fatih, "Pesantren dalam Kebijakan Sisdiknas", Error! Hyperlink reference not valid., diakses tanggal 7 Februari 2013.

Undang-Undang Republik Indonesia Nomor 20 Tahun 2003 tentang "Sistem Pendidikan Nasional" Jakarta: Asa Mandiri, 2008.

Uno, Hamzah. B., Perencanaan Pembelajaran, Jakarta: Bumi Aksara, 2009.

Zuhairini, Sejarah Pendidikan Islam, Jakarta: Bumi Aksara, 2004. 